\title{
Mixed sugarcane and elephant grass silages with or without bacterial inoculant
}

\author{
Jucilene Cavali ${ }^{1}$, Odilon Gomes Pereira², Sebastião de Campos Valadares Filho², Marlos \\ Oliveira Porto ${ }^{1}$, Francisco Eden Paiva Fernandes ${ }^{1}$, Rasmo Garcia ${ }^{2}$
}

${ }^{1}$ Pós-graduação em Zootecnia pela Universidade Federal de Viçosa - UFV/MG.

2 Departamento de Zootecnia da Universidade Federal de Viçosa - UFVIMG. Pesquisador do CNPq.

\begin{abstract}
The effects of different ratios of sugarcane and elephant grass (0:100, 25:75, 50:50, 75:25 and 100:0\% of the natural basis) were assessed on the chemical composition and losses in silages treated with a bacterial inoculant, using laboratory silos. A $2 \times 5$ factorial arrangement (with and without inoculant and five elephant grass ratios) in a randomized blocks design with three replications was used. Interaction was observed in the sugarcane and elephant grass ratio $\times$ bacterial inoculant for crude protein (CP) and $\mathrm{pH}$. The other variables were influenced only by the increasing proportions of elephant grass. The contents of dry matter, neutral detergent fiber corrected for ashes and protein, acid detergent fiber, insoluble protein in acid detergent fiber, hemicellulose and lignin in the silages increased linearly with the proportions of elephant grass. The water soluble carbohydrate contents and dry matter in vitro digestibility of the silages decreased linearly with the increase in the proportion of elephant grass. The mean value of ammonia nitrogen in relation to total $\mathrm{N}$ was $7.0 \%$ (\% of DM). The CP values of the inoculated and non-inoculated silage fitted linear models. The highest CP content was observed in the silage treated with inoculant. The $\mathrm{pH}$ values of the silages, with and without inoculant, fitted quadratic and linear models, respectively. The lactic acid, propionic acid and butyric acid contents were not influenced by the elephant grass ratios, while the acetic acid content, for the non-inoculated silages, and ethanol decreased linearly with the increase in elephant grass. The ratio of $25 \%$ sugarcane and 75\% elephant grass improves the nutritional value and increases the silage DM recovery, because of the lower effluent and gas productions. The homofermentative bacterial inoculant does not affect the sugarcane silage.
\end{abstract}

Key Words: effluent, ethanol, nutritional value, organic acids, soluble sugars

\section{Silagens mistas de cana-de-açúcar e capim-elefante com ou sem inoculante bacteriano}

RESUMO - Avaliou-se o efeito de diferentes relações de cana-de-açúcar e capim-elefante (0:100; 25:75; 50:50; 75:25 e 100:0\% na matéria natural) sobre a composição química e as perdas em silagens tratadas com inoculante bacteriano utilizando-se silos laboratoriais. Adotou-se um esquema fatorial $2 \times 5$ (com e sem inoculante e cinco proporções de capim-elefante), em delineamento inteiramente casualizado, com três repetições. Observou-se interação relação cana e capim-elefante $\times$ inoculante para a composição em proteína bruta (PB) e o pH. As demais variáveis foram influenciadas apenas pelas relações crescentes de capim-elefante. Os teores de MS, fibra em detergente neutro corrigida para cinzas e proteína, fibra em detergente ácido, proteína insolúvel em detergente ácido, hemicelulose e lignina nas silagens aumentaram linearmente com as proporções de capim-elefante. Por sua vez, o teor de carboidratos solúveis e a digestibilidade in vitro da MS das silagens decresceu linearmente com o aumento da proporção de capim-elefante. O valor médio do nitrogênio amoniacal foi de 7,0\% na MS. Os valores de PB das silagens inoculadas e não-inoculadas ajustaram-se a modelos lineares, crescentes e decrescentes, respectivamente. Observou-se maior teor de $\mathrm{PB}$ nas silagens tratadas com inoculante. Os valores de $\mathrm{pH}$ das silagens, com e sem inoculante, ajustaram-se a modelos quadráticos e lineares, respectivamente. Os teores de ácido lático, propiônico e butírico não foram influenciados pelas proporções de capim-elefante, enquanto os teores de ácido acético, no caso das silagens não-inoculadas, e de etanol decresceram linearmente com o aumento do nível de capim-elefante. A relação de $25 \%$ de cana-de-açúcar e $75 \%$ de capim-elefante melhora o valor nutricional e aumenta a recuperação da MS ensilada, em decorrência das mais baixas produções de efluentes e gases. O inoculante bacteriano homofermentativo não tem efeito na silagem de cana-de-açúcar.

Palavras-chave: ácidos orgânicos, açúcares solúveis, efluente, etanol, valor nutricional 


\section{Introduction}

The increase in the herd size has led the farmers to choose sugarcane silage to make feeding management more efficient and use excess production in dry season of the year. However, tropical grasses present some undesirable characteristics in the fermentation process in the silo that makes it difficult to obtain good quality silage.

Elephant grass is characterized by low dry matter content (DM), high buffering power and low water soluble carbohydrate contents at the young stage of maturity, characteristic of secondary fermentations during ensilage (Evangelista et al., 2004). However, it presents fast physiological maturity and short delays in cutting cause modifications in the chemical composition that harms forage digestibility in the rumen (Deschamps, 1999) that justifies ensilage with the use of additives. On the other hand, silages of sugarcane alone are characterized by excess of soluble carbohydrates, that result in intense alcohol fermentation resulting from the biochemical reactions catalyzed by yeast fermentation, with a high production of carbon dioxide, water and ethanol (Siqueira et al., 2007), that causes reductions of up to $440 \mathrm{~g} / \mathrm{kg}$ in the water soluble carbohydrate content, increase in the fibrous components (Schmidt et al, 2007) and DM loses (Alli et al., 1983).

Mixed silages of elephant grass and sugarcane are alternatives for using more mature elephant grass, because this acts as absorbent material and raises the silage DM content, blocking the fermentative pathway of alcohol production (Alli et al., 1982) and reducing effluent production. On the other hand, sugarcane can be used as a source of readily fermentable sugars in ensilage of tropical forage plants.

Microbial inoculants improve the fermentation process of grass silages and their effects are more expressive in grass silages than in silages of corn and sorghum, because the reduced water soluble carbohydrate contents and epiphyte bacteria populations suitable for good fermentation (Meeske et al., 1999). However, when using inoculants based on homofermentative lactic bacteria to sugarcane, the lactic acid resulting from homolactic fermentation can be used as substrate by yeasts to synthesize undesirable by-products (Nussio \& Schmidt, 2005).

The objective of this study was to assess the chemical composition and losses in the fermentation of mixed silages of sugarcane and elephant grass in different proportions, associated or not to bacterial inoculant.

\section{Material and Methods}

The experiment was carried out at Departmento de Zootecnia of Universidade Federal de Viçosa, in the municipality of Viçosa, at $20^{\circ}$ and $45^{\prime}$ latitude South, $42^{\circ}$ and 51' longitude West and $657 \mathrm{~m}$ altitude, where the mean annual rainfall is $1341 \mathrm{~mm}$ of which about $86 \%$ occur from October to March. The maximum mean temperature is $26.1{ }^{\circ} \mathrm{C}$ and the mean minimum temperature is $14.0^{\circ} \mathrm{C}$.

The sugarcane variety (Saccharum officinarum IAC86-2480) and elephant grass (Pennisetum purpureum $\mathrm{cv}$. Cameroon) cut at $15 \mathrm{~cm}$ from the soil surface were harvested manually with the help of a machete at 18 (sugarcane a year and a half old, of intermediate cycle and characteristics suitable for silage) and five months of age, when they were 1.9 and $1.5 \mathrm{~m}$ tall, respectively, and were then chopped into particles of approximately $2 \mathrm{~cm}$, in a stationary forage chopper. Both the grasses came from already established plantations where only organic fertilizer (cattle manure) had been applied during the year.

The ratios of sugarcane and elephant grass at ensilage were $0: 100,25: 75,50: 50,75: 25$ and $100: 0 \%$ on the natural basis, associated or not to the bacterial inoculant Master Silo, from Biotrade Industry e Commercial, with the following levels guaranteed in its composition: lactic acid bacteria (LAB): Lactobacillus plantarum and Pediococcus acidilactici $\left(2.5 \times 10^{10} \mathrm{ufc} / \mathrm{g}\right)$. The bacterial inoculant was applied according to the manufacturer's recommendations, using a hand sprayer.

A $2 \times 5$ factorial arrangement (with and without inoculant and five elephant grass ratios) in a randomized blocks design with three replications was used. The material was ensiled in $18 \mathrm{~L}$ plastic buckets (experimental silos), with lids fitted with a Bunsen valve to allow the fermentation gases to escape. Three kilograms of dry sand were placed at the bottom of the bucket, separated from the forage by a cloth, for later effluent production estimation. The mean specific mass or compacting density of the buckets containing only sugarcane and elephant grass was 833 and $666 \mathrm{~kg}$ forage $/ \mathrm{m}^{3}$, respectively.

The silos were sealed with adhesive tape, weighed and stored in a covered area, at ambient temperature, until opening, 40 days after the ensilage. At this time, they were weighed again to quantify the losses from fermentation, and samples were collected to determine the $\mathrm{pH}$, ammonia nitrogen $\left(\mathrm{NH}_{3}-\mathrm{N}\right)$ and one sample was frozen for later determination of lactic, propyonic and butyric acids.

A $500 \mathrm{~g}$ sample was removed in triplicate from each treatment (elephant grass:sugarcane ratio, inoculated or not) at ensilage for the pre-drying, and samples were taken 
from the silages referent to the replications of each treatment, placed in paper bags and taken to a forced air circulation chamber at $60 \pm 5^{\circ} \mathrm{C}$ for 72 hours, and then ground into $1 \mathrm{~mm}$ particles in a Wiley type grinder. The following were determined in these processed samples: dry matter (DM), neutral detergent fiber (NDF), acid detergent fiber (ADF), hemicellulose and lignin, ammonia/total nitrogen $\left(\mathrm{NH}_{3}-\mathrm{N}\right)$, water soluble carbohydrates (WSC) and apparent in vitro dry matter digestibility in 48 hours (IVDMD) according Silva \& Queiroz (2002); neutral detergent fiber corrected for ash and protein (NDFap), according to Hall (2003); and the analyses of neutral detergent insoluble protein (NDIP) and acid detergent insoluble protein (ADIP) according to the description of Licitra et al. (1996). The ruminal bacterial inoculant for in vitro incubation was removed from crossbred cattle, enfistulated in the rumen and fed $2 \mathrm{~kg}$ concentrate and pure chopped sugarcane ad libitum.

To determine the $\mathrm{pH}, 25 \mathrm{~g}$ samples were collected to which $100 \mathrm{~mL}$ distilled water were added and the $\mathrm{pH}$ was read after for two hours rest, using a potentiometer. In another $25 \mathrm{~g}$ sample, $200 \mathrm{~mL}$ of a $\mathrm{H}_{2} \mathrm{SO}_{4}, 0.2 \mathrm{~N}$ solutions were added and was allowed to rest for 48 hours in a refrigerator and was then filtered through Whatman ${ }^{\circledR} 54$ filter paper. The $\mathrm{NH}_{3}-\mathrm{N}$ content as a percentage of the $\mathrm{N}$-total was dosed in the filtrate using $\mathrm{KOH}$ at 2 Normal. Another sample of approximately $500 \mathrm{~g}$ was removed from each silo and kept in a freezer $\left(-5^{\circ} \mathrm{C}\right)$ to determine organic acids and ethanol. These samples were sent to the Departamento de Zootecnia at the Escola de Veterinária at UFMG. After thawing, the samples were pressed to obtain the silage juice and later analyses of ethanol and lactic, propyonic and butyric acid by gas chromatography (AOAC, 1980) in a Shimadzu CG-17A apparatus with a NUKOL capillary column.

Dry matter losses in the forms of gas and effluent were quantified by weight difference, following methodology reported by Siqueira et al (2007). Gas losses (g/kg of DM) were calculated based on the difference in weight of the dry forage mass, by the difference from the full bucket at closing and at the opening of the silo $(\mathrm{kg})$ divided by the forage mass at closing $(\mathrm{kg}) \times$ forage dry matter content at closing $\times 1,000$. Loss through effluent ( $\mathrm{kg} /$ ton fresh matter) was calculated by the difference in weight of the sand $(\mathrm{kg})$ related to the forage mass $(\mathrm{kg})$ at silo closing $\times 100$. The dry matter recovery index $(\mathrm{g} / \mathrm{kg}$ ) was obtained from the difference in weight of the forage mass $(\mathrm{kg})$ at ensilage and the opening of the silo and their respective dry matter contents $(\mathrm{g} / \mathrm{kg})$.

The data obtained were submitted to analyses of variance and regression, using the SAEG 8.0 version (UFV, 2000). The t-test at 5\% was applied to compare the means for the qualitative factor (inoculant). The regression equations were chosen based on the coefficient of determination and on the significance of the coefficients of regression, using t test.

\section{Results and Discussion}

Values were observed of 285 and $275 \mathrm{~g} / \mathrm{kg}$ and 317 and $329 \mathrm{~g} / \mathrm{kg}$ for the dry matter contents of the sugarcane and elephant grass in the absence and presence of microbial inoculant, respectively (Table 1). These values were higher than those recommended by McDonald et al. (1991) as necessary to reduce losses through effluents in the silo while maintaining the nutrients in the silage.

The values recorded for sugarcane were similar to those reported by Bernardes et al. (2007), while those observed for elephant grass resulted from its advanced stage of maturity at harvest.

The values observed for the other variables (Table 1) except for those for the elephant grass crude protein were in line with the mean values reported by Valadares Filho et al. (2006) for the respective grasses. The low crude protein contents for elephant grass may have been related to the absence of maintenance fertilization, because only cattle manure was applied to the grass cultivation area.

Regarding the soluble carbohydrate contents, mean values of 375 and $103 \mathrm{~g} / \mathrm{kg}$ were a recorded for the sugarcane and elephant grass, respectively. McCullough (1977) recommended soluble carbohydrate contents greater than $80 \mathrm{~g} / \mathrm{kg}$ of the dry matter and moisture content close to $700 \mathrm{~g} / \mathrm{kg}$ as potential for ensilage of a plant. However, Haigh (1990) suggested that there was an inverse relation between the need for sugars and the dry matter content of the forage to obtain proper fermentation. Van Soest (1994) reported that the SC: buffering capacity ratio should be high, to obtain good-quality silage, if the dry matter content of the forage is reduced.

The analysis of variance showed effect $(\mathrm{P}<0.05)$ of the grass ratios $\mathrm{x}$ bacterial inoculant for the crude protein and $\mathrm{pH}$ variables. The other variables assessed were influenced only by increase in the grass proportions (Table 2).

The dry matter contents of the silages increased linearly with the increase in the grass ratios (Table 2) estimating values of 258 and $313 \mathrm{~g} / \mathrm{kg}$ for silages with 0 and 100\% elephant grass, respectively. This fact was due to the higher dry matter content in the elephant grass compared to the sugarcane.

It is important to point out the reduction in dry matter content of the silage made from sugarcane alone $(258 \mathrm{~g} / \mathrm{kg})$ 
Table 1 - Chemical composition and in vitro digestibility of dry matter of the grasses before ensilage, in function of the sugarcane and elephant grass ratios, with or without bacterial inoculant

\begin{tabular}{|c|c|c|c|c|c|c|c|c|c|c|}
\hline \multirow[t]{3}{*}{ Variable } & \multicolumn{10}{|c|}{ Rations of sugarcane and elephant grass ( $\mathrm{g} / \mathrm{kg}$ as fed basis) } \\
\hline & \multicolumn{2}{|c|}{$100: 0$} & \multicolumn{2}{|c|}{$75: 25$} & \multicolumn{2}{|c|}{$50: 50$} & \multicolumn{2}{|c|}{$25: 75$} & \multicolumn{2}{|c|}{$0: 100$} \\
\hline & NI & INOC & NI & INOC & NI & INOC & NI & INOC & NI & INOC \\
\hline Dry matter (g/kg) & 285 & 275 & 280 & 289 & 301 & 312 & 315 & 318 & 317 & 329 \\
\hline Organic matter (g/kg of $\mathrm{DM})$ & 869 & 811 & 895 & 873 & 832 & 938 & 937 & 933 & 933 & 936 \\
\hline Crude protein $(\mathrm{g} / \mathrm{kg}$ of $\mathrm{DM})$ & 18.6 & 17.0 & 19.4 & 19.1 & 19.6 & 20.7 & 21.3 & 21.3 & 20.7 & 21.7 \\
\hline $\begin{array}{l}\text { Neutral detergent insoluble protein } \\
(\mathrm{g} / \mathrm{kg} \text { of } \mathrm{CP})\end{array}$ & 417 & 429 & 352 & 480 & 264 & 592 & 413 & 357 & 354 & 499 \\
\hline Water soluble carbohydrate (g/kg of DM) & 382 & 368 & 314 & 272 & 161 & 193 & 120 & 153 & 102 & 103 \\
\hline Neutral detergent fiber ( $\mathrm{g} / \mathrm{kg}$ of $\mathrm{DM}$ ) & 471 & 488 & 608 & 609 & 687 & 696 & 766 & 769 & 794 & 808 \\
\hline $\begin{array}{l}\text { Neutral detergent fiber corrected for } \\
\text { ash and crude protein ( } \mathrm{g} / \mathrm{kg} \text { of } \mathrm{DM})\end{array}$ & 430 & 448 & 576 & 589 & 664 & 663 & 755 & 751 & 783 & 786 \\
\hline Acid detergent fiber ( $\mathrm{g} / \mathrm{kg}$ of $\mathrm{DM}$ ) & 254 & 257 & 331 & 353 & 395 & 388 & 443 & 456 & 460 & 489 \\
\hline Ammonia nitrogen ${ }^{3}$ & 6.14 & 5.77 & 4.92 & 5.64 & 4.30 & 4.55 & 4.17 & 4.71 & 3.62 & 3.58 \\
\hline
\end{tabular}

$1 \%$ total nitrogen. NI: not inoculated; INOC: inoculated; IVDMD: in vitro digestibility of dry matter.

Table 2 - Chemical composition of the silages in function of the sugarcane and elephant Grass rations, treated or not with bacterial inoculants

\begin{tabular}{|c|c|c|c|c|c|c|}
\hline \multirow[t]{2}{*}{ Inoculant } & \multicolumn{5}{|c|}{ Rations of sugarcane and elephant grass (g/kg as $\mathrm{NM})^{1}$} & \multirow[t]{2}{*}{ CV (\%) } \\
\hline & 100:0 & $75: 25$ & $50: 50$ & $25: 75$ & $0: 100$ & \\
\hline \multicolumn{7}{|c|}{ Dry matter $(\mathrm{DM})(\mathrm{g} / \mathrm{kg})$} \\
\hline \multirow[t]{2}{*}{ Not-inoculated } & 258 & 281 & 303 & 310 & 310 & 2.26 \\
\hline & \multicolumn{5}{|c|}{ Organic matter (g/kg of $\mathrm{DM})$} & \multirow{3}{*}{0.62} \\
\hline Inoculated & 943 & 938 & 933 & 931 & 930 & \\
\hline Not-inoculated & 946 & 942 & 937 & 934 & 928 & \\
\hline \multirow[t]{2}{*}{ Not-inoculated } & $15 \mathrm{~B}$ & $22 \mathrm{~A}$ & $22 \mathrm{~A}$ & $22 \mathrm{~A}$ & $24 \mathrm{~A}$ & 8.87 \\
\hline & \multicolumn{5}{|c|}{ Neutral detergent insoluble protein $(\mathrm{g} / \mathrm{kg}$ of $\mathrm{PB})$} & \multirow{3}{*}{38.44} \\
\hline Inoculated & 215 & 307 & 395 & 449 & 408 & \\
\hline \multirow[t]{2}{*}{ Not-inoculated } & 355 & 301 & 383 & 419 & 402 & \\
\hline & \multicolumn{5}{|c|}{ Acid detergent insoluble protein (g/kg of $\mathrm{PB}$ ) } & \multirow[b]{2}{*}{9.80} \\
\hline Inoculated & 224 & 229 & 276 & 264 & 271 & \\
\hline Not-inoculated & \multicolumn{5}{|c|}{ Neutral detergent fiber (g/kg of DM) } & \multirow{3}{*}{2.74} \\
\hline Inoculated & 629 & 692 & 734 & 770 & 808 & \\
\hline \multirow[t]{2}{*}{ Not-inoculated } & 679 & 725 & 727 & 774 & 808 & \\
\hline & \multicolumn{5}{|c|}{ Neutral detergent fiber corrected for ash and crude protein $(\mathrm{g} / \mathrm{kg}$ of $\mathrm{DM})$} & \\
\hline Inoculated & 585 & 654 & 697 & 732 & 774 & 3.21 \\
\hline \multirow[t]{2}{*}{ Not-inoculated } & 639 & 688 & 688 & 738 & 778 & \\
\hline & \multicolumn{5}{|c|}{ Acid detergent fiber (g/kg of DM) } & \\
\hline Inoculated & 362 & 394 & 425 & 450 & 458 & 4.98 \\
\hline Not-inoculated & 390 & 422 & 427 & 458 & 499 & \\
\hline & & & ose $(g / \mathrm{l}$ & & & \\
\hline Inoculated & 267 & 298 & 309 & 321 & 349 & 6.60 \\
\hline Not-inoculated & 289 & 307 & 298 & 315 & 309 & \\
\hline
\end{tabular}

${ }^{1} \mathrm{NM}$ : natural matter. ${ }^{2}$ Means in the column followed by different letters are different $(\mathrm{P}<0.05)$ by $\mathrm{t}$ test. 
compared to the value of the sugarcane at ensilage (280 g/kg). This performance was not expected, because in this silage and in the silage containing $250 \mathrm{~g} / \mathrm{kg}$ elephant grass there was higher effluent losses (Table 4). Siqueira et al. (2007) also observed reductions in the dry matter contents of in natura sugarcane, with and without inoculants, of 352 and 353 to 274 and $291 \mathrm{~g} / \mathrm{kg}$ in their silages, respectively, a fact that can be explained by the reduction in the water soluble carbohydrate contents by the alcohol fermentation, that resulted in a proportional increase in the contents of cell wall constituents (Bernardes et al., 2007).

The residual sugars contents in the silage decreased linearly $(\mathrm{P}<0.05)$ as the ratios of elephant grass increased at ensilage (Table 3 ). This fact was explained by the smaller sugar content in the elephant grass compared to sugarcane. However, according to Woolford (1984) a higher residual sugar content may result in greater aerobic deterioration when the silo is opened, because it favors the growth of yeasts that ferment sugars, such as those of the Torulopsis genius that thus interfered in their aerobic stability.
Tosi et al. (1995), ensiled “Napier” elephant grass with the addition of $30 \%$ sugarcane and reported an increase of approximately $50 \%$ in the water soluble carbohydrate content (from 114.4 to $176.4 \mathrm{~g} / \mathrm{kg}$, \% of DM) and concluded that sugarcane inclusion was not favorable for production of good-quality silage for some fermentation parameters such as organic acids and $\mathrm{pH}$, probably because sugarcane and elephant grass with a low dry matter contents were used.

The linear increase in neutral detergent fiber corrected for ash and protein, acid detergent fiber and hemicellulose contents of silages (Table 3 ) as elephant grass was added was due not only to the increase in the fibrous fractions derived from the more mature elephant grass, but also to the effect of the concentration of these fibrous constituents in dry matter silage, because part of the sugars was used by the microorganisms during the fermentation process. A similar performance was reported by Siqueira et al. (2007).

The lignin content also increased linearly $(\mathrm{P}<0.05)$ with the addition of elephant grass, a fact related to the higher value of this constituent in elephant grass compared to sugarcane. Normally, the lignin content in relation to the neutral detergent fiber content is negatively correlated to

Table 3 - Regression equations fitted to the silages in function of the increase in the elephant grass (EG) ratio in sugarcane silages, treated or not with bacterial inoculant

\begin{tabular}{|c|c|c|}
\hline Variable & Regression Equation & $\mathrm{R}^{2}$ \\
\hline Dry matter (g/kg) & $\hat{Y}=266.599+0.5918 * E G$ & 0,86 \\
\hline Organic matter ${ }^{1}$ & $\hat{Y}=944.109-0.1548 * \mathrm{EG}$ & 0,98 \\
\hline \multirow[t]{2}{*}{ Crude protein ${ }^{1}$} & $\hat{\mathrm{Y}}=24.6440-0.02487 * \mathrm{EG}(\mathrm{I})$ & 0,80 \\
\hline & $\hat{\mathrm{Y}}=17.9926+0.07148 * \mathrm{EG}(\mathrm{NI})$ & 0,71 \\
\hline Neutral detergent insoluble protein ${ }^{2}$ & $\hat{Y}=36,34$ & \\
\hline \multirow[t]{2}{*}{ Acid detergent insoluble protein ${ }^{2}$} & $\hat{Y}=227.400-0.5130 * E G^{(I)}$ & 0,87 \\
\hline & $\hat{Y}=204.961-01.3696 * E G(N I)$ & 0,69 \\
\hline Water soluble carbohydrate ${ }^{1}$ & $\hat{Y}=121.171-0.7914 * E G$ & 0,93 \\
\hline Neutral detergent fiber ${ }^{1}$ & $\hat{Y}=661.617+147.229 * \mathrm{EG}$ & 0,98 \\
\hline Neutral detergent fiber corrected for ash and crude protein $^{1}$ & $\mathrm{Y}=619.228+156.676 * \mathrm{EG}$ & 0,98 \\
\hline Acid detergent fiber ${ }^{1}$ & $\hat{Y}=378.592+1.0028 * E G$ & 0,99 \\
\hline Hemicellulose ${ }^{1}$ & $\hat{Y}=283.025+0.4694 * E G$ & 0,94 \\
\hline Lignin $^{1}$ & $\hat{Y}=62.217+4.4526 * \mathrm{EG}$ & 0,96 \\
\hline in vitro dry matter digestibility ${ }^{1}$ & $\hat{Y}=486.591-1.2317 * E G$ & 0,95 \\
\hline
\end{tabular}

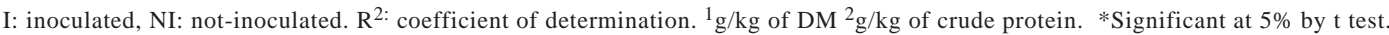

Table 4 - Fermentation parameters of the silages in function of the sugarcane and elephant grass ratios, treated or not with bacterial inoculant

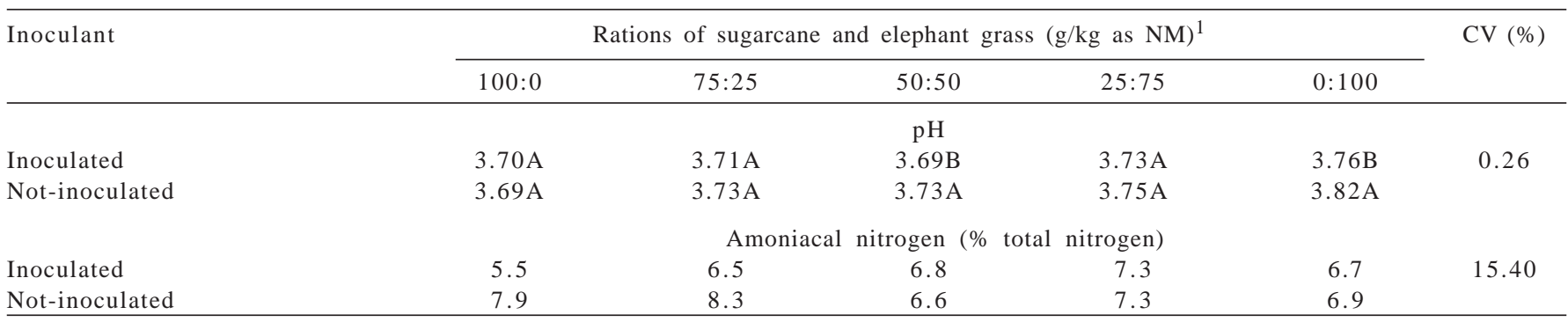

Means in the column followed by different letters differ $(\mathrm{P}<0.05)$ by $\mathrm{t}$ test. ${ }^{1} \mathrm{NM}$ : natural matter. 
degradation of the fibrous fraction, because lignin prevents digestion of the cell wall carbohydrates at approximately 1.4 times its own weight (Van Soest, 1981).

Analysis of the effect of inoculant within the grass ratios showed greater crude protein content $(\mathrm{P}<0.05)$ in the inoculated silage only at the proportion zero elephant grass (Table 2). On the other hand, when the crude protein contents were analyzed in function of the increasing portions of elephant grass, reductions and increases of 0.0024 and 0.0071 units per unit of elephant grass added to the inoculated and non-inoculated silages, were estimated, respectively (Table 3). Similar results were reported by Almeida et al. (1986). The increase in crude protein in the non-inoculated silages was probably due to the effect of the concentration of this fraction on the water soluble sugar losses.

Regarding the neutral detergent insoluble protein contents, no regression equation fitted the data, and a mean value of $363 \mathrm{~g} / \mathrm{kg}$ of crude protein was registered. Regarding the acid detergent insoluble protein contents, it was observed that both the inoculated and non-inoculated silages were influenced by the increases of elephant grass proportions, and an increase of 0.05130 and 0.13696 unit per unit of elephant grass added was estimated, respectively (Table 3). This performance can be explained by the increase in acid detergent fiber content in the silages with the increase of elephant grass proportions.

High acid detergent insoluble protein content implying unavailability of nitrogen forms for ruminal microbial fermentation (Van Soest, 1994). All ensiled forage has unavailable protein as a result of plant physiology and the processes that lead to excessive heating of the ensiled mass (McDonald, 1981; Rotz \& Muck, 1994). However, Weiss et al. (1992) stated that up to $300 \mathrm{~g} / \mathrm{kg}$ of the acid detergent insoluble nitrogen can be considered available to the animal.

The in vitro dry matter digestibility of the silages decreased linearly $(\mathrm{P}<0.05)$ as the ratios of elephant grass increased (Table 3). Considering that acid detergent fiber is the component that most relates to digestibility, this performance can be explained by the increase in acid detergent fiber with the increase in elephant grass. Silveira et al. (1973) added 30\% sugarcane to "Napier" elephant grass at ensilage and reported an improvement in silage quality, observing in vitro dry matter digestibility of 524, 492 and $489 \mathrm{~g} / \mathrm{kg}$, respectively, for pre-wilted elephant grass silages with the addition of sugarcane, and for silages of elephant grass alone.

There was plant species $\mathrm{x}$ inoculant interaction for the silage $\mathrm{pH}$. When the inoculant effect within the same elephant grass proportion was assessed, a lower $(\mathrm{P}<0.05)$ $\mathrm{pH}$ value was observed in the silages inoculated at the ratios of 50 and $100 \%$ elephant grass (Table 4 ).

However, although significant $(\mathrm{P}<0.05)$, the numerical difference in the $\mathrm{pH}$ for these elephant grass ratios was not very expressive and, when assessed together with the ammonia and butyric acid contents (Table 5), the occurrence of secondary fermentation was discounted, mainly because of the multiplication of bacteria of the Clostridium genus and protein degradation (McDonald et al., 1991).

When the $\mathrm{pH}$ was analyzed in function of the elephant grass ratios, quadratic and linear effects were observed for inoculated and non-inoculated silages, respectively (Table 6). In the first case, a minimum value of 3.4 was

Table 5 - Fermentation parameters of the silages with various sugarcane and elephant grass ratios treated or not with bacterial inoculant

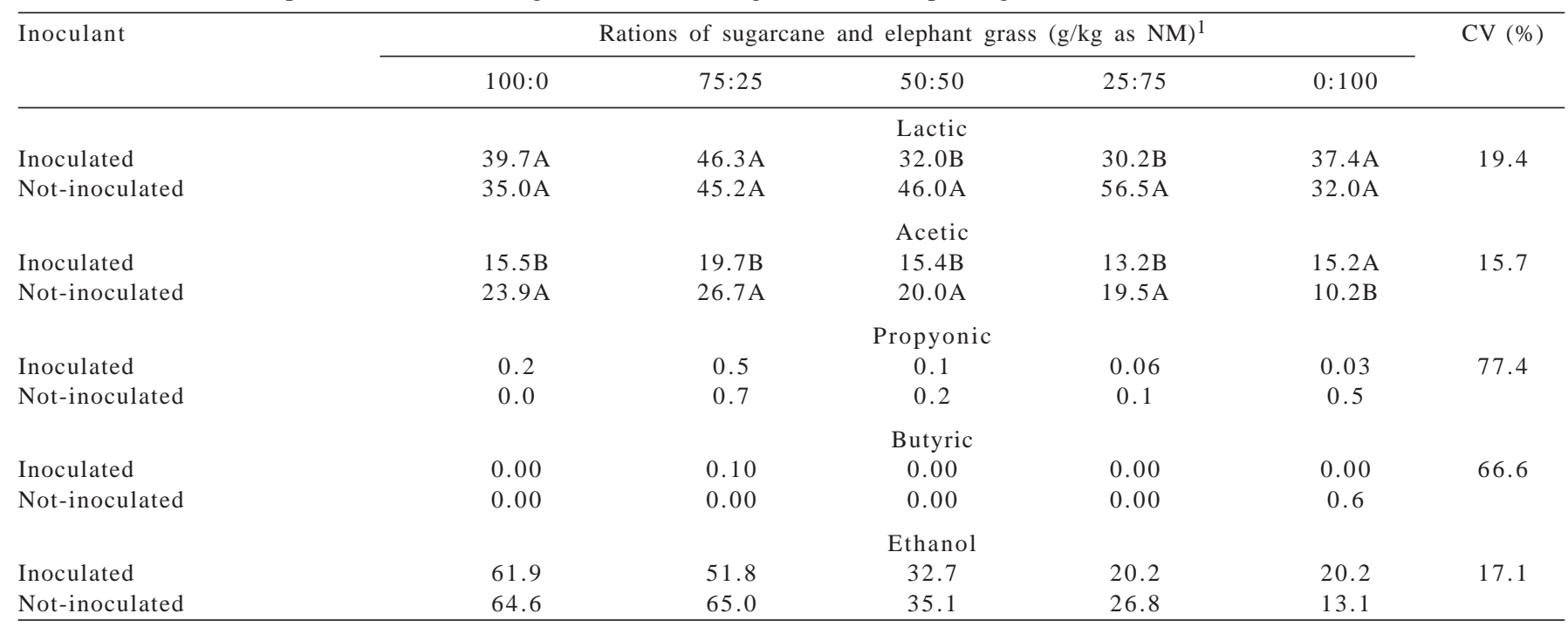

Means in the column followed by different letters differ $(\mathrm{P}<0.05)$ by t test. ${ }^{1} \mathrm{NM}$ : natural matter. 
estimated for $28 \%$ of elephant grass level. However, undesirable fermentation in sugarcane is characterized by yeast development and not by clostridium, as occurs in other forages, such as tropical grasses, corn and sorghum. Thus the $\mathrm{pH}$ and ammonia nitrogen parameters, even reduced, when considered alone, where not good indicators to assess the fermentation quality of the silages, because the ethanol produced functioned as a microbial inhibitor on most of the microorganism species. Therefore the focus should be control of losses from alcohol production and yeast development during fermentation and after opening the silos (Bernardes et al., 2007).

A rapid fall in the $\mathrm{pH}$ and a low final $\mathrm{pH}$ can help to decrease the population of microorganisms that are harmful to ensilage, that produced a large quantity of acetic and butyric acids (Van Soest, 1994). The ammonia nitrogen data did not fit any model, and a mean value of $7.0 \%$ was recorded. Based on this value, Pahlow et al. (2003) defined a maximum limit of $12 \%$ ammonia nitrogen for grass silages.

The data for the lactic acid contents did not fit any regression equation and a mean value of $40 \mathrm{~g} / \mathrm{kg}$ on the dry matter was recorded (Table 6). Valadares Filho et al. (2006) reported a value of $44.5 \mathrm{~g} / \mathrm{kg}$ of lactic acid for elephant grass silage with up to $40 \%$ sugarcane.

Evaluation of the bacterial inoculant effect, within the same grass proportions showed higher lactic acid values $(\mathrm{P}<0.05)$ for the non-inoculated silages at the proportions of 50 and $75 \%$ elephant grass. More recent results have been consistent in showing absence of effect or harmful effect of homofermentative bacteria inoculation in sugarcane silages (Ribeiro et al., 2005; Freitas et al., 2006). This fact may be explained by the large production of lactic acid resulting from homolactic fermentation, which is used as substrate by yeasts for ethanol synthesis (McDonald et al., 1991). Better results regarding the use of inoculants in sugarcane silages have been obtained when heterolatic bacteria such as $L$. buchneri were used

Table 6 - Regression for silage fermentation parameters as function of elephant grass (EG) ratios

\begin{tabular}{|c|c|c|}
\hline Variable & Equation & $\mathrm{R}^{2}$ \\
\hline $\mathrm{pH}$ & $\begin{array}{l}\hat{Y}=3.7079-0.00068 \mathrm{C}+0.000012 * \mathrm{EG}^{2(\mathrm{I})} \\
\hat{\mathrm{Y}}=3.6880+0.00113 * \mathrm{EG}^{(\mathrm{NI})}\end{array}$ & $\begin{array}{l}0.81 \\
0.87\end{array}$ \\
\hline $\begin{array}{l}\text { Amoniacal nitrogen }{ }^{1} \\
\text { Lactic acid }{ }^{2} \\
\text { Acetic acid }\end{array}$ & $\begin{array}{l}\hat{Y}=7.01 \\
\hat{Y}=40.0 \\
\hat{Y}=17.8 \\
\hat{Y}=269875-0138) * F G \quad(\mathrm{NI})\end{array}$ & 076 \\
\hline $\begin{array}{l}\text { Propyonic acid } \\
\text { Butyric acid }\end{array}$ & $\begin{array}{l}\hat{Y}=0.26 \\
\hat{Y}=0.08\end{array}$ & \\
\hline Ethanol $^{2}$ & $\begin{array}{l}\hat{Y}=67.3923-0.5464 * \mathrm{EG}^{(\mathrm{I})} \\
\hat{\mathrm{Y}}=60.3446-0.5989 * \mathrm{EG}{ }^{(\mathrm{NI})}\end{array}$ & $\begin{array}{l}0.96 \\
0.93 \\
\end{array}$ \\
\hline
\end{tabular}

I: inoculated and NI: non-inoculated. $\mathrm{R}^{2}$ : coefficient of determination, $1 \%$ total nitrogen. ${ }^{2} \mathrm{~g} / \mathrm{kg}$ of DM $*$ Significant at $5 \%$, by t test.
(Pedroso et al., 2007). According to Siqueira et al (2007) the use of $L$. buchneri resulted in reduced alcohol production and dry matter losses during sugarcane ensilage in function of the greater acetic acid content and $41 \%$ reduction in the alcohol content compared to the silage without additive, thus contributing to smaller dry matter loss in the form of gas.

Interaction effect was detected $(\mathrm{P}<0.05)$ for the acetic acid and ethanol contents in the silages. The acetic acid contents, for the non-inoculated silages, fitted the linear model and reductions of 0.013 percentage unit were estimated (Table 6). No equation fitted the data for the inoculated silages and a mean value of $17.8 \mathrm{~g} / \mathrm{kg}$ on the dry matter was recorded.

Small acetic acid concentrations are important in fermentation because their anti-fungus effect is more efficient than lactic acid (Moon, 1983). The acetic acid values for the silage were lower than the minimum values of $200 \mathrm{mmol} \mathrm{L}^{-1}$ indicated for a $50 \%$ yeast reduction (Moon, 1983).

However, smaller acetic acid concentrations were observed in the inoculated silages and in greater proportions of sugarcane compared to the non-inoculated silages. This was probably due to predominant homolactic fermentation, favored by the inoculant, which restricted the development of acetic acid producing bacteria, as Kung et al. (2003) and Muck \& Kung (1997) suggested.

Regarding the propyonic acid and butyric acid contents, no regression equation fitted the data, and mean values of 0.026 and $0.008 \%$ were recorded on the DM, respectively. The propyonic acid concentrations in the silage were within the range from zero to $10 \mathrm{~g} / \mathrm{kg}$ to be classified as goodquality silage, as reported by Mahanna (1993).

The ethanol contents fitted a decreasing linear model, and reductions of 0.054 and 0.059 units were estimated per unit of elephant grass added, for the inoculated and noninoculated silages, respectively. These results were predictable because of the higher yeast concentration in the silages with greater sugarcane proportions, as reported previously. The ethanol values of sugarcane silage alone were similar to those reported by other authors, with values ranging from 69 to $80 \mathrm{~g} / \mathrm{kg}$ (Andrade et al., 2001; Bernardes et al., 2007; Pedroso et al., 2007). Losses through gases are very important at sugarcane silage because they are highly correlated to the ethanol content $(903 \mathrm{~g} / \mathrm{kg})$ and to the dry matter recovery (893 g/kg) (Pedroso et al., 2007).

Gas and effluent losses decreased linearly with the increase in the proportions of elephant grass in the silage (Table 7), and reductions of 0.14522 and 0.51385 units per 
Table 7 - Dry matter losses in silages with various sugarcane and elephant grass ratios, treated or not with bacterial inoculant

\begin{tabular}{|c|c|c|c|c|c|c|}
\hline Inoculant & \multicolumn{5}{|c|}{ Rations of sugarcane and elephant grass $(\mathrm{g} / \mathrm{kg} \text { as } \mathrm{NM})^{1}$} & CV $(\%)$ \\
\hline & \multicolumn{5}{|c|}{ Gases $(\mathrm{g} / \mathrm{kg}$ of $\mathrm{DM})$} & \multirow{2}{*}{4.15} \\
\hline \multirow[t]{2}{*}{ Not-inoculated } & 189 & 130 & 87 & 49 & 28 & \\
\hline & \multicolumn{5}{|c|}{ Effluent (kg/t of fed basis) } & 11.17 \\
\hline Not-inoculated & \multicolumn{5}{|c|}{ Dry matter recovery (g/kg of DM) } & \multirow{3}{*}{2.58} \\
\hline Inoculated & 804 & 869 & 929 & 966 & 979 & \\
\hline Not-inoculated & 820 & 915 & 947 & 959 & 960 & \\
\hline
\end{tabular}

${ }^{1} \mathrm{NM}$ : natural matter. ${ }^{2} \mathrm{DM}$ : dry matter.

unit elephant grass added were estimated, that may have been associated to the increase in the dry matter content of the silages with the addition of elephant grass, as reported in the present study, that directly influenced the reduction in undesirable fermentation in the silo (Table 8).

The dry matter losses through effluents involved values from 5 to $10 \%$ (Woolford, 1984) and had a highly pollutant potential, attributed to their high biochemical demand for oxygen (Pereira e Bernardino, 2004).

Losses during fermentation depend of fermented nutrients and microorganisms involved. Dry matter losses resulting from lactic acid bacteria activity, in practice, were between 2 and 5\% (McDonald et al., 1991). When there is alcohol production (ethanol or manitol) there is a considerable increase in losses through gases that increased the dry matter losses through carbon dioxide production. This type of fermentation is promoted by heterofermentive bacteria, enterobacteria and yeasts (Driehuis \& Van Wikselaar, 1999). Under conditions of excess moisture, the dry matter losses through gases are even greater, because of butyric fermentation, promoted by clostridium, because both the dry matter and energy losses are high (McDonald et al., 1991). As the dry matter contents were lower in the silages with higher sugarcane ratios and these silages had higher sugar contents, there was a suitable environment for yeast development that explained the greater losses by gases in these silages.

Table 8 - Regression fitted for dry matter losses of sugarcane silages with various sugarcane and elephant grass (EG) ratios, treated or not with bacterial inoculant

\begin{tabular}{lcc}
\hline Variable & Equation & $\mathrm{R}^{2}$ \\
\hline Gás $^{1}$ & $\hat{\mathrm{Y}}=165.396-01.4522 *$ EG & 0,98 \\
Effluent $^{2}$ & $\hat{\mathrm{Y}}=58.0854-0.51358 *$ EG & 0,91 \\
Dry matter recovery $^{1}$ & $\hat{\mathrm{Y}}=837.944+01.5466 *$ EG & 0,88 \\
\hline
\end{tabular}

$\mathrm{R}^{2}$ : coefficient of determination. ${ }^{1} \mathrm{~g} / \mathrm{kg}$ of DM. ${ }^{2} \mathrm{~kg} / \mathrm{t}$ fresh matter. * significant at $5 \%$, by t test.

\section{Conclusions}

The proportion of $25 \%$ sugarcane and $75 \%$ elephant grass at ensilage improves the nutritional value and increases the ensiled dry matter recovery, because of the lower productions of ethanol, effluents and gases. The homofermentative bacterial inoculant has no effect on the sugarcane ensilage.

\section{References}

ALLI, I.; BAKER, B.E.; GARCIA, G. Studies on the fermentation of chopped sugarcane. Animal Feed Science and Technology, v.7, n.4, p.411-417, 1982.

ALLI, I.; FAIRBAIRN, R.; BAKER, B.E. et al. The effects of ammonia on the fermentation of chopped sugarcane. Animal Feed Science and Technology, v.9, n.4, p.291-299, 1983. ALMEIDA, E.X.; PINTO. J.C.; PÉREZ, J.R.O. Cama de frango e cana-de-açúcar na qualidade da silagem de Pennisetum purpureum Schum. cv. Cameroon. Revista da Sociedade Brasileira de Zootecnia, v.15 n.3, p.193-199, 1986.

ANDRADE, J.B.; FERRARI, J.R.E.; BRAUN, G. Valor nutritivo da silagem de cana de açúcar tratada com uréia e acrescida de rolãode-milho. Pesquisa Agropecuária Brasileira, v.36, n.9, p.1169-1174, 2001.

ANUALPEC, 2006. Anuário da pecuária brasileira. São Paulo, FNP Consultoria \& Comércio, 2006. 369p.

ASSOCIATION OF OFFICIAL AGRICULTURAL CHEMISTS - AOAC. Official methods of analysis. 13.ed. Washington, 1980. 1015p.

BERNARDES, T.F.; REIS. R.A.; SIQUEIRA, G.R. et al. Avaliação da queima e da adição de milho desintegrado com palha e sabugo na ensilagem de cana-de-açúcar. Revista Brasileira de Zootecnia, v.36, n.2, p.269-275, 2007.

DESCHAMPS, F.C. Implicações do período de crescimento na composição química e digestão dos tecidos de cultivares de capimelefante (Pennisetum purpureum Schumach.). Revista Brasileira de Zootecnia, v.28, n.6, p.1358-1369, 1999.

DRIEHUIS, F.; VAN WIKSELAAR, P.G. In: WORKSHOP. A Regulation of silage fermentation, XII th INTERNATIONAL SILAGE CONFERENCE, Uppsala, Sweden. Proceedings... Uppsala. 1999. p.133-134.

EVANGELISTA, A.R.; LIMA, J.A.; ABREU, J.G. et al. Produção de silagem de capim marandu (Brachiaria brizantha stapf cv. Marandu) com e sem emurchecimento. Ciência Agrotécnica, v.28, n.2, p.446-452, 2004 
FREITAS, A.W.P.; PEREIRA, J.C.; ROCHA, F.C. et al. Avaliação da qualidade nutricional da silagem de cana-de-açúcar com aditivos microbianos e enriquecida com resíduo da colheita de soja. Revista Brasileira de Zootecnia, v.35, n.1, p.38-47, 2006.

HAIGH, P.M. Effect of herbage water-soluble carbohydrate content and weather conditions at ensilage on the fermentation of grass silages made on commercial farms. Grass and Forage Science, v.45, n.3, p.263-271, 1990.

HALL, M.B. Challenges with nonfiber carbohydrate methods. Journal of Animal Science, v.81, n.12, p.3226-3232, 2003.

KUNG JR., L.; STOKES, M.R.; LIN, C.J. Silage additives. In: BUXTON, D.R.; MUCK, R.E.; HARRISON, J.H. (Eds.) Silage science and technology. Madison: American Society of Agronomy, Crop Science Society of America, Soil Science Society of America, 2003. p.251-304.

LICITRA, G.; HERNANDEZ, T.M.; VAN SOEST, P.J. Standardization of procedures for nitrogen fractionation of ruminant feeds. Animal Feed Science and Technology, v.57, n.4, p.347-358, 1996.

MAHANNA, B. Troubleshooting silage problems. In: STATE APPLIED NUTRITION CONFERENCE, 4., 1993, Wisconsin. Proceedings... Wisconsin, 1993. p.1-24.

McDONALD, P. The biochemistry of silage. Nova York: John Wiley \& Sons, 1981. 226p.

McDONALD, P.; HENDERSON, A.R.; HERON, S.J.E. The biochemistry of silage. 2.ed. Mallow Chalcombe Publications, 1991, 340p.

McCULLOUGH, M.E. Silage and silage fermentation. Feedstuffs, v.49, n.13, p.49-50, 1977.

MEESKE, R.; BASSON, H.M.; CRUYWAGEN, C.W. The effect of lactic acid and bacterial inoculant with enzymes on the fermentation dynamics, intake and digestibility of Digitaria eriantha silage. Animal Feed Science and Technology, v.81, n.3/4, p.237-248, 1999.

MOON, N.J. Inhibition of the growth of acid tolerant yeasts by acetate, lactate and propionate and their synergistic mixtures. Journal of applied Bacteriology, v.55, n.3, p.453-460, 1983

MUCK, R.E.; KUNG JR., L. Effects of silage additives on ensiling. In: SILAGE: FIELD TO FEEDBUNK. NRAES-99, 1997, Herchey. Proceedings... Herchey, NRAES, 1997. p.187-199.

NUSSIO, L.G.; SCHMIDT, P. Silagens de cana-de-açúcar para bovinos leiteiros: aspectos agronômicos e nutricionais. In: SIMPÓSIO SOBRE BOVINOCULTURA LEITEIRA, 5., Piracicaba, 2005. Anais... Piracicaba: FEALQ, 2005. p.193-218.

NUSSIO, L.G.; SCHMIDT, P.; PEDROSO, A.F. Silagem de canade-açúcar In: EVANGEISTA, A.R.; REIS, S.T.; GOMIDE, E.M. (Eds.) Forragicultura e pastagens: Temas em evidência Sustentabilidade. Lavras: Editora UFLA, 2003. p.49-72.

PAHLOW, G.; MUCK, R.E.; DRIEHUIS, F. et al. Microbiology of ensiling. In: BUXTON, D.R.; MUCK, R.E.; HARRISON, J.H. (Eds.) Silage science and technology. 1.ed. Madison: American Society of Agronomy, 2003. p.31-94.
PEDROSO, A.F.; NUSSIO, L.G.; LOURES, D.R.S. et al. Efeito do tratamento com aditivos químicos e inoculantes bacterianos nas perdas e na qualidade de silagens de cana-de-açúcar. Revista Brasileira de Zootecnia, v.36, n.3, p.558-564, 2007.

PEREIRA, O.G.; BERNARDINO, F.S. Controle de efluentes na produção de silagem. In: SIMPÓSIO SOBRE MANEJO ESTRATÉGICO DA PASTAGEM, 2., 2004, Viçosa, MG. Anais... Viçosa, MG, 2004. p.509-545.

RIBEIRO, J.L.; QUEIROZ, O.C.M.; NUSSIO, L.G. Desenvolvimento de aditivos microbianos para ensilagem. In: REIS, R.A.; SIQUEIRA, G.R.; BERTIPAGLIA, L.M.A. (Eds.) Volumosos na produção de ruminantes. Jaboticabal: Funep, 2005. p.1-24.

ROTZ, C.A.; MUCK, E.R. Changes in forage quality during harvest and storage. In: FAHEY JR., G.C.; MOSER, L.E.; MERTENS, D.R. et al. (Eds.) Forage quality, evaluation and utilization. Madison: ASA, 1994. p.828-868.

SCHMIDT, P.; NUSSIO, L.G.; ZOPOLLATTO, M. et al. Aditivos químicos ou biológicos na ensilagem de cana-de-açúcar. 2. Parâmetros ruminais e degradabilidade da matéria seca e das frações fibrosas. Brazilian Journal of Animal Science, v.36, n.5, p.1676-1684, 2007 (suppl.)

SIQUEIRA, G.R.; REIS, R.A.; SCHOCKEN-ITURRINO, R.P. et al. Perdas de silagens de cana-de-açúcar tratadas com aditivos químicos e bacterianos. Revista Brasileira de Zootecnia, v.36, n.6, p.2000-2009, 2007 (supl.)

SILVA, D.J.; QUEIROZ, A.C. Análise de alimentos: métodos químicos e biológicos. 3.ed. Viçosa, MG: Universidade Federal de Viçosa, 2002. 165p.

SILVEIRA, A.C.; TOSI, H.; FARIA, V.P. et al. Efeito de diferentes tratamentos da digestibilidade in vitro de silagens do capim Napier (Pennisetum purpureum Schum.). Revista Brasileira de Zootecnia, v.2, n.2, p.216-26, 1973.

TOSI, H.; RODRIGUES, L.R.A.; JOBIM, C.C. et al. Ensilagem do capim-elefante cv. Mott sob diferentes tratamentos. Revista Brasileira de Zootecnia, v.24, n.6, p.909-916, 1995.

UNIVERSIDADE FEDERAL DE VIÇOSA - UFV. SAEG Sistema de análises estatísticas e genéticas. Versão 8.0 . Viçosa, MG: 2000. 150p. (Manual do usuário).

VALADARES FILHO, S.C.; MAGALHÃES, K.A.; ROCHA JR., V.R. et al. Tabelas brasileiras de composição de alimentos para bovinos. 2.ed. Viçosa, MG: Suprema Gráfica Ltda.; Universidade Federal de Viçosa, 2006. 329p.

VAN SOEST, P.J. Limiting factors in plant residues of low biodegradability. Agricultural and Environmental, v.6, n.4, p.135-143, 1981.

VAN SOEST, P.J. Nutritional ecology of the ruminant. 2.ed. Ithaca: Cornell University Press, 1994. 476p.

WEISS, W.P.; CONRAD, H.R.; ST PIERRE, N.R. A theoreticallybased model for predicting total digestible nutrient values of forages and concentrates. Animal Feed Science and Technology, v.39, n.1-2, p.95-110, 1992.

WOOLFORD, M,K. The silage fermentation. New York: Marcel Dekker, 1984. 350p. 